\title{
KAMPUNG KONSERVASI SUNGAI
}

\author{
Gaguk Sukowiyono \\ Dosen Prodi Arsitektur, Fak. Teknik Sipil dan Perencanaan, ITN Malang \\ gaquksukowiyono@yahoo.com \\ Arief Setiyawan \\ Dosen Prodi PWK, Fak. Teknik Sipil dan Perencanaan, ITN Malang \\ arf setiyawan@yahoo.com \\ Mohammad Erfan \\ Dosen Prodi Teknik Sipil, Fak. Teknik Sipil dan Perencanaan, ITN Malang \\ Erfan mla@yahoo.co.id
}

\begin{abstract}
ABSTRAK
Pelestarian sungai merupakan awal dari pemikiran dan ide dalam Kampung Konservasi Sungai yang terletak di desa Tunjungsekar kecamatan Lowokwaru kota Malang. Fungsi sungai sebagai sumber kehidupan masyarakat sekitar hendaknya dapat dipertahankan keberadaanya. Kualitas airnya belum banyak tercemar, diupayakan untuk dilestarikan dengan cara dikonservasi.

Kawasan kampung tepian sungai masih longgar dengan bangunan, masyarakatnya masih mengandalkan banyak terhadap keberadaan sungai, dan didukung lingkungan hijaunya sawah. Kondisi ini banyak menarik investor untuk membangun perumahan di sekitarnya. Akibatnya sungai bukan lagi sebagai tempat kehidupan namun sudah berfungsi sebagai tempat buangan limbah sehingga kualitas lingkungan dan air sungai yang ada menurun.

Dengan melihat kondisi seperti itu, maka perlu untuk dipertahankan kondisi lingkungannya dengan konsep-konsep pelestarian sungai. Pengumpulan dan pengolahan data dilakukan secara terus menerus dan selanjutnya dianalisa secara diskriptif untuk dibuatkan konsep-konsep yang mengacu pada konservasi sungai yang nantinya dituangkan dalam sketsa desain rancangan. Diskusi mematangkan konsep dilakukan secara berkala dengan melibatkan unsur terkait.
\end{abstract}

Kata kunci : sungai, kondisi lingkungan, konservasi

\section{Latar Belakang}

\section{PENDAHULUAN}

Kawasan Tunjungsekar merupakan kawasan yang masuk dalam rencana pengembangan Kota Malang. Keberagaman penduduk dan 
pekerjaannya menggambarkan perkembangan sektor ekonomi penduduknya cukup baik. Dilewatinya wilayah ini oleh sungai yang dimanfaatkan penduduk sekitar sebagai sumber kehidupan sehingga perlu dijaga dan dilestarikan keberadaannya.

Posisi wilayah RW.04 kelurahan Tunjungsekar yang terletak di utara kota Malang yang berbatasan dengan kabupaten Malang merupakan kawasan yang didominasi persawahan sehingga lingkungannya masih alamiah dan jauh dari pencemeran membuat kawasan ini menarik investor untuk membangun tempat bermukim.

Pembangunan perumahan banyak didirikan di tepian sungai karena potensi view sebagai alasan utamanya. Pembuangan limbah perumahan di arahkan ke sungai, ancaman kerusakan lingkungan sungai dan kualitas airnya dapat berakibat buruk terhadap kehidupan masyarakat kampung yang ada disepanjang aliran sungai ini.

\section{Perumusan Masalah}

Perkembangan permukiman dan penataan kawasan di tepian sungai harus diperhatikan. Ketersediaan pendukung lingkungan yang kurang memadai akan mengakibatkan terjadinya gangguan, misal: pembuangan limbah langsung ke sungai tanpa proses pengolahan, akibatnya akan terjadi pencemaran sungai yang cukup beresiko untuk pemenuhan kebutuhan hidup sehingga perlu dilakuan suatu konservasi agar kualitas air menjadi baik.

\section{Tujuan dan Sasaran}

Tujuan yang ingin dicapai adalah sebagai berikut:

- Konservasi dan pelestarian sungai; wisata edukasi lingkungan dan teknologi sederhana; peningkatan perekonomian masyarakat; menciptakan lapangan kerja dan mengurangi pengangguran

Sasarannya adalah sebagai berikut:

- Sepanjang aliran sungai mulai dari Kelurahan Tasikmadu sampai Kelurahan Tunjungsekar; masyarakat RW.04 khususnya dan kelurahan Tunjungsekar umumnya; masyarakat kota Malang secara keseluruhan; alih teknologi dan IPTEK

\section{Lingkup Perancangan}

Daerah aliran sungai yang menjadi tempat berlangsungnya proses biofisik hidrologis maupun kegiatan sosial, ekonomi, dan budaya masyarakat sekitar meliputi segala aspek pengembangan baik itu lingkungan, IPTEK, sosial, ekonomi dan budaya. 


\section{TINJAUAN PUSTAKA}

\section{Tanaman Konservasi}

Jenis-jenis tanaman konservasi yang bisa diterapkan pada lahan di pinggir sungai adalah sebagai berikut:

\section{a. Bambu}

Kemampuannya menjaga ekosistem air. Sistem perakarannya sangat rapat sehingga lahan menjadi stabil. Bambu memiliki batang yang kuat dan lentur yang tahan dari terpaan angin. Karakter tersebut cocok dijadikan tanaman penghijauan, terutama di daerah aliran sungai (DAS).

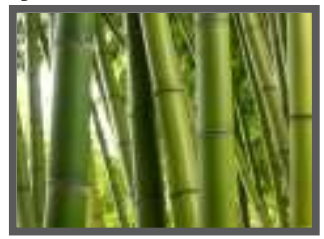

Gambar 1.

Jenis bambu yang banyak tumbuh di Indonesia

\section{b. Kelapa Sawit.}

Ketinggian pohon dapat mencapai 24 meter. Berakar serabut, pohonnya dapat berdiri tegak dan sangat kokoh. Penampilannya mirip tanaman salak dengan duri yang tidak terlalu keras dan tajam. Batang tanaman diselimuti bekas pelepah sehingga penampilan mirip pohon kelapa.

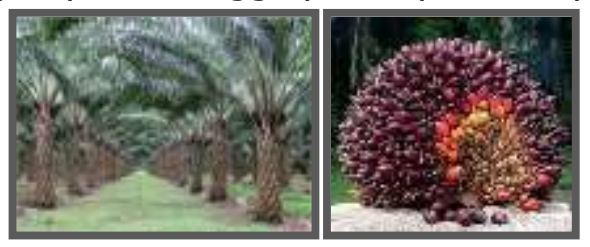

Gambar 2.

Bentuk tanaman dan buah kelapa sawit

\section{c. Eceng Gondok}

Eceng gondok adalah jenis tumbuhan air mengapung. Eceng gondok memiliki kecepatan tumbuh yang tinggi sehingga dapat merusak lingkungan perairan. Eceng gondok dengan mudah menyebar melalui saluran air ke badan air lainnya.

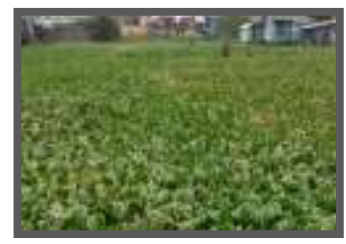

Gambar 3.

Bentuk tanaman enceng gondok

PAWON: Jurnal Arsitektur, Volume II Nomor 02, Juli-Desember 2018, ISSN 2597-7636 


\section{d. Beringin.}

Pohon beringin tumbuh dengan akar gantung yang berkembang dan kadang menyatu dengan batang utamanya sehingga batangnya berbentuk tidak beraturan dan kayunya kurang dimanfaatkan secara optimal.

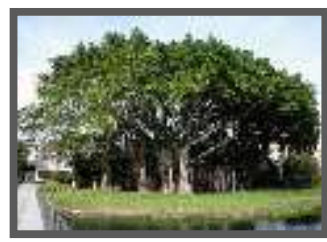

Gambar 4.

Jenis pohon beringin

Kelebihan dan kekurangan dari tanaman konservasi sungai dapat dilihat dalam tabel berikut:

\begin{tabular}{|c|c|c|c|}
\hline NO & TANAMAN & KELEBIHAN & KEKURANGAN \\
\hline$\overline{11}$ & BAMBU & $\begin{array}{l}\text { - Kemampuannya dalam menjaga ekosistem air, } \\
\text { sistem perakaran tanaman bambu sangat rapa. } \\
\text { - Akar-akarnya menyebar kesegala arah baik } \\
\text { menyamping atupun kedalam. Lahan tanah yang } \\
\text { ditumbuhi rumput bambu bisanya menjadi sangat } \\
\text { stabil. }\end{array}$ & $\begin{array}{l}\text { - Semakin susah bambu yang ditemukan, } \\
\text { kurangnya tanaman bambu yang ditanam. }\end{array}$ \\
\hline 2 & $\begin{array}{l}\text { KELAPA } \\
\text { SAWIT }\end{array}$ & $\begin{array}{l}\text { - Kebun sawit memiliki } 3 \text { mekanisme secara sinergis } \\
\text { dalam melindungi tanah dan air. Ketiga mekanisme } \\
\text { tersebut adalah mekanisme : Struktur, kanopi, dan } \\
\text { mekanisme tata kelola. }\end{array}$ & $\begin{array}{l}\text { - Perseolan tata ruang, dimana monokultur, } \\
\text { homogenitas yang overloads konservasi } \\
\text { - Hilangnya keanekaragaman hayati ini akan } \\
\text { memicu kerentanan kondisi alam berupa } \\
\text { menurunya kualita lahan serta erosi, hama dan } \\
\text { penyakit, pembukaan lahan sering kali } \\
\text { dilakukan dengan cara tebang habis dalam land } \\
\text { clearing dengan cara pembakaran demi } \\
\text { efesiensi biaya dan waktu. }\end{array}$ \\
\hline 3 & $\begin{array}{l}\text { ECENG } \\
\text { GONDOK }\end{array}$ & $\begin{array}{l}\text { - Eceng gondok dapat meningkatkan kualitas air. } \\
\text { Karena ia dapat menyerap radikal bebas dalam } \\
\text { air.mampu beradaptasi danhidup dengan baik } \\
\text { diberbagai kondisi air. la juga dapat tumbuh di air } \\
\text { yang bersih ataupun kotor. }\end{array}$ & $\begin{array}{l}\text { - Tanaman eceng gondok tidak dapat hidup di } \\
\text { perairan ekstrim yang mengandung bahan } \\
\text { kimia yang pekat dan bersuhu tinggi, misalnya } \\
\text { di perairan dekat pembuangan limbah pabrik }\end{array}$ \\
\hline 4 & BERINGIN & $\begin{array}{l}\text { Tanaman beringin memiliki kemampuan sebagai } \\
\text { tanaman konservasi mata air dan penguat lereng } \\
\text { alami. Hal tersebut dapat dlihat dari struktur } \\
\text { perangkarannya yang dalam dan akar lateral yang } \\
\text { mencengkeram tanah dengan baik. }\end{array}$ & $\begin{array}{l}\text { - Akar yang terlalu besar membuat kerusakan } \\
\text { mengurangi ruang cukup banyak dalam area } \\
\text { konservasi karena pohon beringin sendiri } \\
\text { memiliki ukuran yang sangat besar dan tinggi. } \\
\text { Membuat ruang sekitar area konservasi } \\
\text { menjadi sempit. }\end{array}$ \\
\hline
\end{tabular}

\section{Gambaran Fisik}

Sungai Tasikmadu-Tunjungsekar terletak di sebelah utara kelurahan Tunjungsekar kecamatan Lowokwaru kota Malang yang berbatasan langsung dengan kelurahan Polowijen, mempunyai panjang $8.647 \mathrm{~m}$ dan lebar $\pm 20 \mathrm{~m}$. Debit air rata-rata maks. $0.456 \mathrm{~m}^{3} /$ detik dan min. 0.228 $\mathrm{m}^{3} /$ detik dengan dasar sungai berbentuk $U$. Arus air lemah dengan kedalaman air rata-rata $\pm 3 \mathrm{~m}$. Kondisi terkini, desakan kuat terhadap sungai adalah berasal dari aktivitas hunian. Hal ini terjadi karena kontrol penggunaan lahan pada sekitar kawasan sungai belum berjalan baik. 


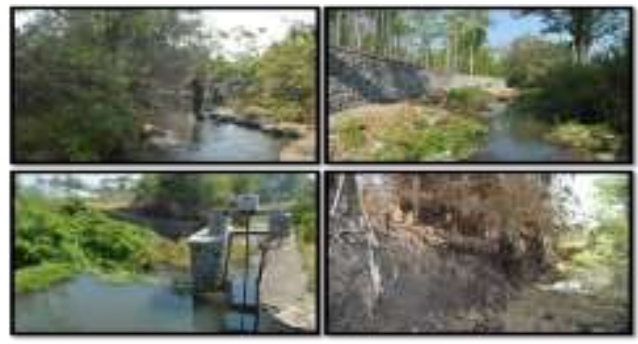

Gambar 5.

Lingkungan sungai Tasikmadu-Tunjungsekar

\section{Obyek Konservasi}

Obyek konservasi berupa sungai Tasikmadu-Tunjungsekar yang terletak di RW. 04 kelurahan Tanjungsekar. Kawasan Tanjungsekar tersebut memiliki potensi yang sangat besar dalam pembangunan.

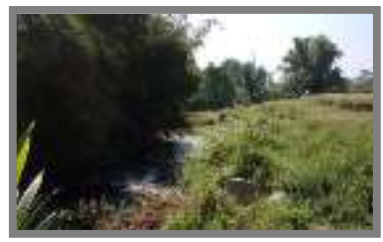

Gambar 6.

Lokasi konservasi sungai Tasikmadu-Tunjungsekar

Sungai Tasikmadu-Tunjungsekar sebagai tempat aliran air hujan sehingga dapat disebut sebagai daerah aliran sungai (DAS) yang perlu dijaga dan dikembangkan keberadaannya.

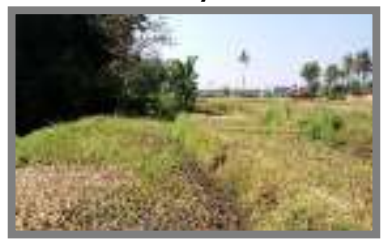

Gambar 7.

Area sawah kelurahan Tunjungsekar

Dengan banyaknya pembangunan perumahan baru disekitar sungai, maka perlu dijaga kelestariannya dengan memperhatikan aspek sosial, ekonomi, dan budaya. Lokasi sungai yang berdekatan dengan perumahan dan persawahan, maka sungai menjadi sumber pembuangan limbah.

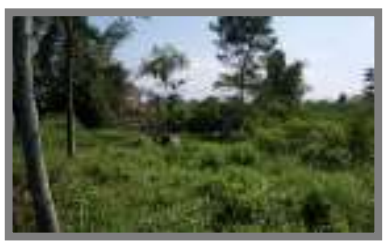

Gambar 8.

PAWON: Jurnal Arsitektur, Volume II Nomor 02, Juli-Desember 2018, ISSN 2597-7636 
Konservasi sungai dapat berupa kegiatan sosial dan kegotongroyongan,yaitu: pengerukan dan perluasan wilayah perlindungan air dan sumber air, operasi dan pemeliharaan sepadan sungai, pengembangan alokasi air, dan water quality control.

\section{METODE PENELITIAN}

\section{Pengumpulan Data}

\section{a. Kondisi eksitensi sungai.}

Kondisi sungai tidak terurus karena banyak sampah dan limbah sisa pembangunan perumahan masuk ke sungai. Dari hasil survey lapangan potensi yang ada, yaitu: hewan air tawar dan tempat wisata pancing.

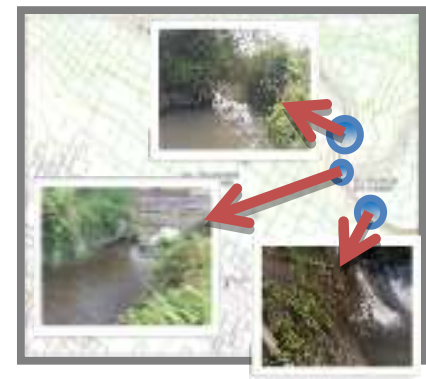

Gambar 9.

Kondisi air sungai Tasikmadu-Tunjungsekar

\section{b. Fisik dan Non fisik Sungai.}

Dari hasil survey di lapangan terlihat beberapa kerusakan di sungaii seperti: dinding penahan yang rusak akibat terkikis air dan penyaring limbah yang sudah rusak dan tidak berfungsi lagi mengakibatkan limbah yang berasal dari penduduk dan area pertanian masuk ke dalam sungai.

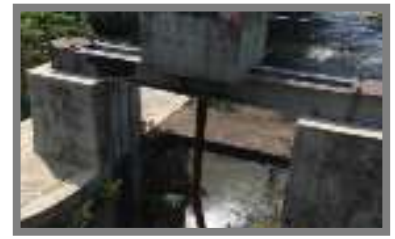

Gambar 10.

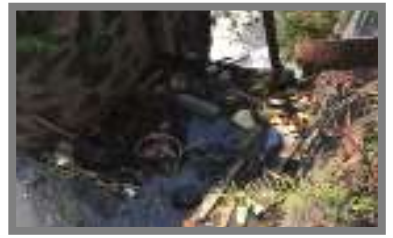

Gambar 11.

Fasilitas sungai yang sudah rusak Limbah yang terbawa air
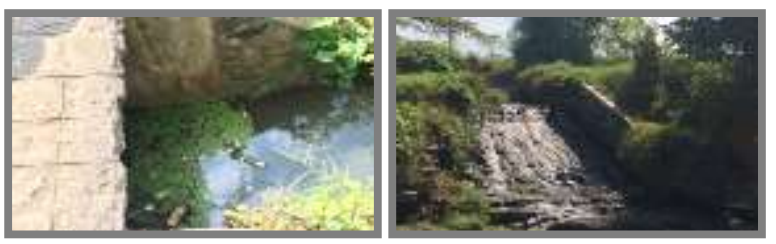

Gambar 12.

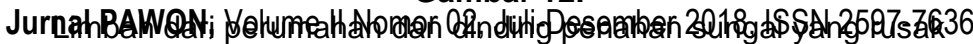




\section{c. Wawancara (warga sekitar, tokoh masyarakat, dan perangkat kelurahan)}

Dari hasil wawancara diketahui bahwa debit air pada aliran sungai ini di musim kemarau sangat rendah (dangkal) dengan kedalaman $\pm 1-2 \mathrm{~m}$. Sedangkan di musim hujan aliran sungai sangat deras dengan kedalaman mencapai \pm 4-6 m, mengakibatkan sampah-sampah (limbah) yang barasal dari penduduk (perumahan), area pertanian dan perkebunan, permukiman warga, klinik kesehatan yang dibuang langsung ke sungai tanpa ada proses pengolahan ikut terbawa aliran sungai seperti terlihat pada gambar di bawah:

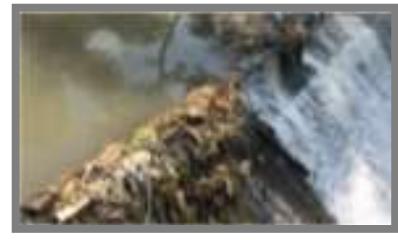

Gambar 13.

Limbah dari perkebunan dan persawahan

\section{HASIL DAN PEMBAHASAN}

\section{Analisa Konservasi Sungai}

Sungai Tasikmadu-Tunjungsekar bagian dari Daerah Aliran Sungai (DAS) yang membelah dari barat-timur wilayah kelurahan TasikmaduTunjungsekar, di Kota Malang. Pesatnya pertumbuhan perumahan baru sekitar DAS berdampak terhadap kualitas lingkungan dan keseimbangan alam sekitar, sehingga perlu dilakukan studi konservasi untuk mendapatkan model pelestarian DAS.
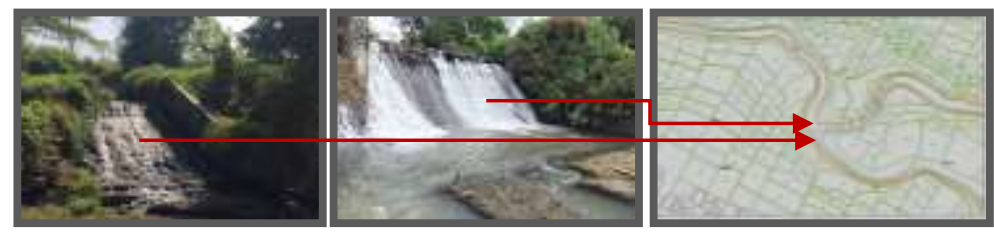

Gambar 14.

Keadaan sungai di pintu air

Gambaran penyaringan air yang tidak berfungsi akibat sampah yang dibuang masyarakat dan tidak dirawat oleh dinas terkait.
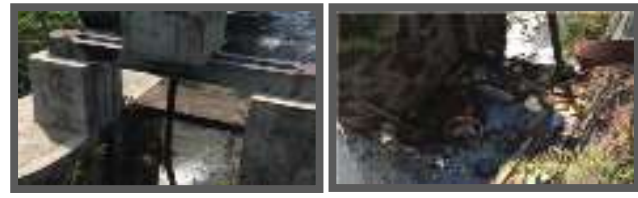

Gambar 15.

PAWON: Jurnal Arsitektur, Volume II Nomor 02, Juli-Desember 2018, ISSN 2597-7636 
Kurangnya kesadaran masyarakat (membuang sampah/limbah ke sungai) membuat sungai Tunjungsekar-Tasikmadu tidak terawat dan tercemar. Adapun sumber limbah dan dampak yang muncul, yaitu:

\section{a. Limbah Permukiman}

Limbah permukiman merupakan limbah rumah tangga (organik) yang terbawa air saluran drainase yang dialirkan langsung ke sungai tanpa diproses terlebih dahulu. Sedangkan limbah rumah tangga yang anorganik dibuang langsung ke sungai. Akibatnya kadar oksigen dalam air turun dratis sehingga biota air akan mati.

\section{Dampak}

Pada saat ini hampir setiap rumah tangga menggunakan deterjen yang limbahnya sukar diuraikan. Penggunaan deterjen berlebihan akan meningkatkan senyawa fosfat yang dapat merangsang pertumbuhan ganggang dan eceng gondok di permukaan air sungai, menutupi masuknya cahaya matahari dan mengakibatkan terhambatnya proses fotosintesis.

\section{b. Limbah Pertanian}

Untuk meningkatkan produksi pertanian, para petani akan menggunakan pestisida guna memberantas hama dan penyakit tanaman, sehingga dapat menimbulkan berbagai dampak negatif.

\section{Dampak}

Kegiatan pertanian telah terbukti dapat menyebabkan pencemaran lingkungan sungai. Pencemaran tersebut terkait dengan pemakaian pestisida yang beracun yang dapat mempengaruhi seluruh ekosistem dalam jangka panjang.

\section{Pengelolaan Pencemaran Sungai}

Salah satu cara untuk mengatasi permasalahan di atas adalah dengan pengelolaan air limbah guna meminimalkan ancaman bagi penduduk sekitar DAS.

\section{a. Pengolahan air limbah}

Pengolahan air limbah ditujukan guna memurnikan air limbah dari permukiman/persawahan yang sudah tercemar menjadi lebih aman untuk dibuang dengan penggunaan teknologi yang tepat agar benarbenar sesuai harapan.

\section{b. Proses pengolahan air limbah}

1. Menghilangkan semua zat padat, sehingga tersisa zat cair saja.

2. Melakukan pemurnian air yang lebih dalam, agar semua zat padat yang tercampur di dalam air limbah benar-benar hilang. 
3. Menghilangkan zat-zat yang tidak dapat dihilangkan pada dua tahap sebelumnya.

4. Mengionisasi dan penyerapan karbon, sehingga air benar-benar aman untuk dibuang dan diuraikan di sungai.

5. Mengolah sisa-sisa 4 proses pengolahan sebelumnya.

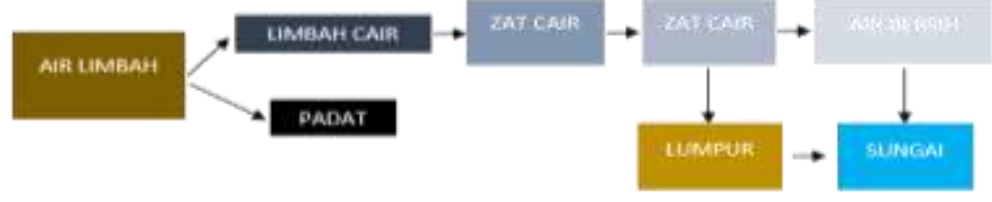

Gambar 16.

Proses pengolahan air limbah

\section{c. Beberapa penggolongan pengolahan air limbah}

1. STP (sewage treatment plan) pengolahan air limbah, adalah limbah yang dihasilkan oleh rumah tangga/kantin/rumah sakit, berupa: deterjen, minyak, dan sisa makanan.

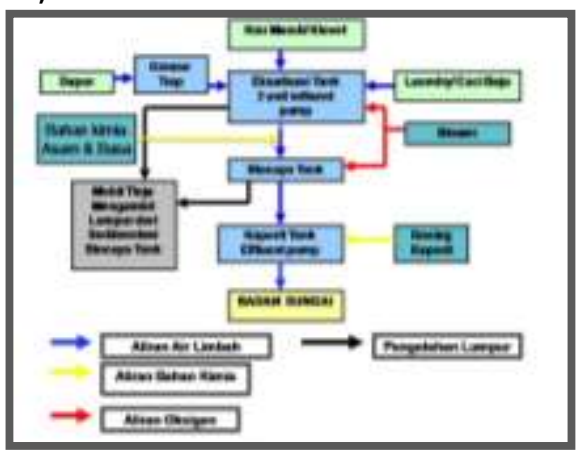

Gambar 17.

STP pengolahan air limbah

2. WWTP (waste water treatment plan) pengolahan air limbah, adalah instalasi pengolahan air limbah (IPAL) yang dibuat untuk mengolah air limbah dari proses produksi, seperti limbah tekstil, limbah percetakan, dan limbah lainnya.

Untuk kasus di sungai Taksimadu-Tunjungsekar, lebih cocok meggunakan pengolahan STP, mengingat di daerah tersebut tidak terdapat daerah industri.

\section{d. Macam-macam teknologi yang digunakan untuk pengolahan air limbah}

1. Clarifier, merupakan proses pengolahan air limbah sederhana, dengan menggunakan chemical yang biasa disebut Koagulan maupun Floakulan untuk mengumpulkan dan mengendapkan kotoran yang tersuspensi/koloid, sehingga dihasilkan air yang bersih. 
2. Ultrafiltrasi, merupakan pengganti dari Clarifier. Ultrafiltrasi banyak digunakan untuk menggantikan fungsi dari clarifier.

3. Bioteknologi, proses pengolahan limbah dengan menggunakan bioteknologi. Limbah diurai tanpa menggunakan zat kimia tambahan tetapi menggunakan bakteri, sehingga menghasilkan air buangan yang aman bagi lingkungan dan kesehatan.

Untuk kasus di sungai Taksimadu-Tunjungsekar, sesuai meggunakan bioteknologi, mengingat resiko dan dampak yang ada sangat kecil.

\section{e. Jenis-jenis pengolahan air limbah}

Jenis pengolahan air limbah dibedakan menjadi tiga jenis yaitu: (1) pengolahan secara fisik, (2) pengolahan secara kimiawi, (3) pengolahan secara biologi.

Untuk kasus di sungai Taksimadu-Tunjungsekar, pegolahan air limbah yang sesuai adalah secara biologi, mengingat limbah dan karakternya.

\section{f. Penghijauan/reboisasi}

Kegiatan pelestarian lingkungan perairan adalah penghijauan/reboisasi pada daerah sepanjang sepadan sungai. Kegiatan reboisasi ini diharapkan mampu menjadi penyerap dan resapan air yang mengalir ke sungai. Pemilihan jenis tanaman yang sesuai dapat membantu proses penahanan daya dukung tanah sebagai resapan air. Salah satunya adalah tanaman bambu. Tanaman ini memiliki sifat perakaran serabut sehingga dapat menstabilkan tanah dan mengurangi erosi, mampu mencegah agar sumber mata air tidak hilang, serta menjaga kebersihan udara karena dapat menghasilkan 30 persen oksigen lebih besar dari pada pohon lainnya.

\section{g. Penataan kawasan}

Tata letak pada kawasan kampung konservasi sungai dibuat sesuai dengan potensi yang dimiliki. Pemanfaatan konservasi sungai jadi sesuatu yang utama yang dapat dijadikan sebagai peningkatan daya dukung kualitas kawasan. Pembagian zona-zona yang terdapat pada lahan yang ada berdasarkan pada kebutuhan akan fungsi lahan sebagai pendukung kawasan, misal: zona edukasi, zona bermain, zona karya penduduk sekitar, zona makan dan minum, zona view, dan lain sebagainya dimana kesemuanya dikelola dan dikembangkan oleh masyarakat sekitar, sehingga dengan begitu akan ada peningkatan sektor ekonomi, perubahan sosian dan budaya masyarakat di kampung konservasi sungai.

Penataan kawasan yang dirancang sedemikian rupa ditujukan untuk mempertegas karakter dari kawasan yang diperkuat dengan jenis-jenis 
vegetasi sebagai unsur estetika selain itu juga berfungsi untuk menjaga air sungai tetap baik kualitasnya serta mampu untuk menahan tanah pada sisi pinggiran sungai.

\section{KESIMPULAN}

Merubah tingkah laku masyarakat tidaklah gampang, seperti pembuangan limbah rumah tangga langsung ke sungai tanpa melalui proses penyaringan, sehingga perlu mengikutsertakan masyarakat secara langsung terhadap pengelolaan lingkungan sungai agar tetap ramah, bebas dari limbah dan enak untuk dilihat. Caranya dengan proses reboisasi dengan menggunakan tanaman konservasi yaitu 'bambu'. Selain itu kondisi lingkungan yang baik dapat dikembangkan sebagai potensi untuk penataan wilayah yang dapat dijadikan sebagai identitas kawasan.

Perlu dilakukan pendampingan kepada masyarakat di lingkungan sungai agar rasa memiliki dan azas manfaat sungai untuk pemenuhan hidup baik fisik maupun non fisik dapat dirasakan, sehingga hal tersebut dapat menjadikan kawasan lingkungan sungai akan semakin baik dan terus meningkat kualitas lingkungannya.

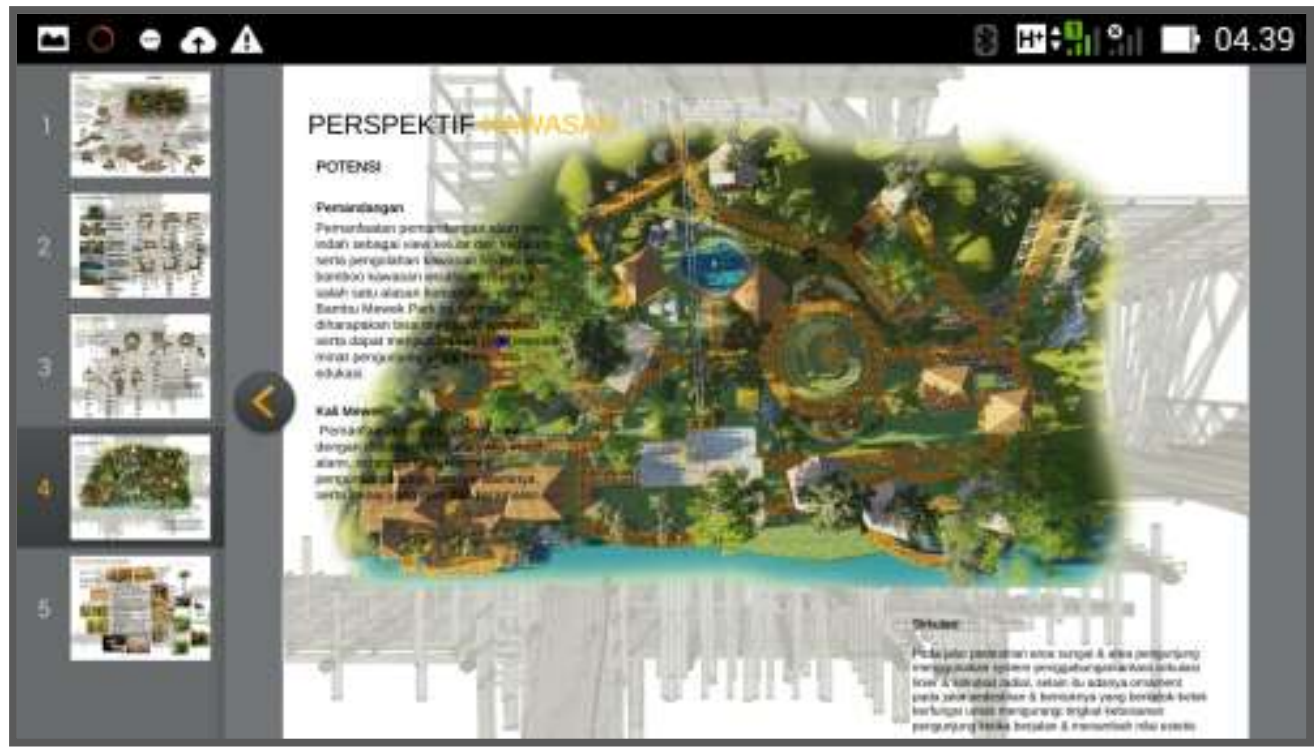

Gambar 18.

Penataan kawasan kampung konservasi sungai

DAFTAR PUSTAKA

Gunadi, Sugeng. 1989. Pedoman Perancangan Tapak dan Lingkungan. Utama Press. Surabaya. 
Hakim, Rustam. 1993. Unsur Perancangan Dalam Arsitektur Lansekap. Penerbit Bumi Aksara. Bandung.

Paimin, dkk. 2012. Sistem Perencanaan Daerah Aliran Sungai. Pusat Penelitian dan Pengembangan Konservasi \& Rehabilitasi (P3KR). Bogor.

Suprayogi Slamet, dkk. 2014. Pengelolaan Daerah Aliran Sungai. Gadjah Mada University Press. Yogjakarta.

Tim Kompas. 2010. Jelajah Musi, Eksotika Sungai di Ujung Senja. Penerbit Buku Kompas.

alamendah.wordpress.com/2010/08/01/pencemaran-air-di-indonesia/

Diana Sofia. 2011. Pengaruh Pestisida Dalam Lingkungan Pertanian. http://repository.usu.ac.id/bitstream/123456789/1106/1/fp-diana.pdf http://www.tirtamandiri.com/pengolahan-air-limbah 